\begin{tabular}{cc|c}
\hline 50 Tarım Bilimleri Dergisi & Journal of Agricultural Sciengeris \\
& $\begin{array}{c}\text { Tar. Bil. Der. } \\
\text { Dergi web sayfası: }\end{array}$ & Journal homepage: \\
& www.agri.ankara.edu.tr/dergi & www.agri.ankara.edu.tr/journal \\
\hline
\end{tabular}

\title{
Assessment of the Quality Losses of Fresh Fig Fruits during Transportation
}

\author{
Bülent ÇAKMAK ${ }^{a}$, Fazilet N. ALAYUNT ${ }^{a}$, R. Cengiz AKDENIZ ${ }^{a}$, Uygun AKSOY ${ }^{b}$, H. Zafer CAN ${ }^{b}$ \\ ${ }^{a}$ Ege University, Faculty of Agriculture, Department of Agricultural Machinery, Bornova-Izmir, TURKEY \\ ${ }^{b}$ Ege University, Faculty of Agriculture, Department of Horticulture, Bornova-Izmir, TURKEY
}

\section{ARTICLE INFO}

Research Article - Agricultural Technologies

Corresponding author: Bülent ÇAKMAK, e-mail: bulent.cakmak@ege.edu.tr, Tel: +90(232) 3884000 / 1505

Received: 03 March 2010, Received in revised form: 10 October 2010, Accepted: 20 October 2010

\begin{abstract}
Turkey is one of the main fig fruits producers in the World. The protection of the fig fruit quality in the chains from harvesting to marketing is very important. Vibration often causes some damages to perishable fruits in transportation and reduces their quality. The fruit injury due to vibration is related to the transportation characteristics of vehicles, packaging boxes and the conditions of the roads. The objective of this study was to investigate the effectiveness of packaging box by different materials to decrease the damages of vertical vibration on the quality of three fresh fig varieties (Yediveren, Sarilop and Bursa Black) during transportation. The experiments were carried out in two stages. In the first stage; the frequency and acceleration values of truck were determined during the real transportation. In the second stage, these values were applied on the simulator (shaker) to examine the effect of vibration on fresh figs packaged with three different boxes. The results showed that the cardboard packaging box was not proper for transporting of the fresh fig fruits in all road conditions. The mass loss of fresh fig fruits packed with cardboard box were found to be 2.5 times more than extruded and expanded polystyrene boxes at $16 \mathrm{~Hz}$ frequency and $2.54 \mathrm{~m} \mathrm{~s}^{-2}$ acceleration. Sarilop fig variety was more damaged under the off-road. For long highway road conditions, Bursa Black fig variety was found the most affected fig variety.
\end{abstract}

Keywords: Fig; Packaging; Polystyrene; Quality; Transport; Vibration

\section{Taze İncir Meyvesinin Taşınması Sırasında Oluşan Kalite Kaybının Değerlendirilmesi}

\section{ESER BÍLGİSI}

Araştırma Makalesi — Tarım Teknolojileri

Sorumlu Yazar: Bülent ÇAKMAK, e-posta: bulent.cakmak@ege.edu.tr, Tel: +90(232) 3884000 / 1505

Geliş tarihi: 03 Mart 2010, Düzeltmelerin gelişi: 10 Ekim 2010, Kabul: 20 Ekim 2010

\section{ÖZET}

Türkiye, incir üretimiyle Dünyanın önemli üreticilerinden birisidir. İncirin kalitesinin korunması hasattan pazara kadar büyük önem arz etmektedir. Titreşim çoğunlukla hassas meyvelere zarar vermekte ve kalitesini düşürmektedir. Titreşim nedeniyle oluşan hasarlar, taşıma yapan aracın karakteristiklerine, paketlemeye ve yol koşularına bağlı olmaktadır. Bu çalışmada, üç çeşit taze incir meyvesinin (Yediveren, Sarılop ve Bursa Siyahı) taşınması sırasında titreşim hasarlarını azaltmak amacıyla farklı malzemeler kullanılarak yapılan kutuların etkinliği araștırılmıștır. Denemeler iki aşamalı olarak gerçekleştirilmiştir. Birinci aşamada, gerçek taşıma koşullarında kamyondaki frekans ve titreşim değerleri saptanmıştır. İkinci aşamada bu değerler, üç farklı kutuyla paketlenen taze incirlerin 
üzerindeki titreşim etkisini saptamak için simülatörde (sarsıcıda) uygulanmıştır. Sonuçlar, bütün yol koşullarında karton kutuların taze incir meyvelerinin taşınması için uygun olmadığını göstermiş̧tir. Karton kutularda taşınan meyvelerdeki kütle kaybı, ekstrüde polistiren ve ekspande polistiren taşıma kutulara göre otoyol taşıma koşularında $\left(16 \mathrm{~Hz}-2.54 \mathrm{~m} \mathrm{~s}^{-2}\right)$ yaklaşık 2.5 kat daha fazla ölçülmüştür. Sarılop incir çeşidi bozuk yolda, Bursa Siyahı çeşidi ise uzun otoyol taşımasında daha fazla hasar gören çeşit olarak belirlenmiştir.

Anahtar sözcükler: İncir; Paketleme; Polistiren; Kalite; Taşıma; Titreşim

\section{Introduction}

Fig (Ficus carica L.) is well adapted to the subtropical and mild temperate climates (Aksoy 1997). It has been a stable food for the indigenous people of Turkey for thousands of years. Fig fruit is a very important dietary food for human health because of its high nutrient value and fiber content and laxative peculiarity. Therefore, it is consumed as fresh or dry in Turkey and worldwide. The bestknown varieties all over the world are Sarilop (Calimyrna), Roxo de Valinhos, Kalamata, Adriatic \& Kadota. The fig is important for Turkish Agricultural Marketing because of being a main production in the world. Turkey provides nearly $1 / 3$ of the world with the production of Sarilop, being its major fig variety for drying.

Generally the main objectives of the producers and researchers are to decrease quality losses of fruit and vegetables during handling. Peleg \& Hinga (1986) stated that discarded agricultural materials because of damage in the chain between the grower and the consumer are reportedly estimated at around $30-40 \%$. Fruits and vegetables are subject to different types of mechanical forces during harvesting, storage and transportation. These are impact, vibration, abrasion, compression bruising and cut by sharp edge. Various studies have been carried out to assess the effects of these stresses on fresh fruits (Bolen \& De La Rue 1990; Burton et al 1989).

Especially, during transportation, fruits and vegetables move randomly in their packages. Duration and intensity of vibration related to the extent of the repeated force and displacement determine the deterioration of fruits and vegetables. When the forces exceed certain limits, the fruits are damaged and then lose their quality. Regarding transportation, frequent attention was devoted to delicate fruits such as apples. Singh \& Xu (1993) reported that as many as $80 \%$ of apples can be damaged during simulated transportation by truck, depending on the type of truck, packaging and position of the container along the column. Damage due to transport vibration was investigated on other species of fruits and vegetables, such as cling peaches (O'Brien et al 1965; Vergano et al 1991; Öğüt et al 1999), apricots (O'Brien \& Guillou 1969), potatoes (Truczyn et al 1986), tomatoes (Singh \& Singh 1992; Özgüven \& Vursavuş 2002), grapes, strawberries (Fisher et al 1992) and apples (Vursavuş \& Özgüven 2004; Acıcan et al 2007). The fact that these damages are noticed in the marketing place means a large amount of financial loss. In many cases, the physical damage will lead to attacks by microorganisms physiological changes, which may increase the deterioration of fragile products. Sommer (1957) found that surface discoloration was caused by vibration in-transit and the surface damage seriously affected market value of product.

Alayunt et al (2000) investigated the effects of vibration, packaging materials on three important fig varieties grown in Turkey. They found that packaging materials affected vibration injury of fruit. In local transportation, cardboard boxes were more suitable for transportation than wooden ones. On the other hand, the authors also expressed that new materials and packaging methods should be investigated and used for transportation of fresh fig fruits because of their fragile structure.

During the transportation, especially round shape fruits and vegetables are rotated by vibration. Repetition displacement of fresh fruits and vegetables causes softening and bruising. Other reason of the damage is sharp corners of the boxes. 
Abrasion or vibration bruise occur against the rough surface or contact the other product. Mechanicaldamaged fruit losses moisture quickly. Damaged fruits exposed to attack of the virus and loss their quality. The fruit injury due to vertical vibration is related to the transportation characteristics of vehicles, the conditions of the roads and boxes (Slaughter et al 1993, 1998; Sommer 1957).

O'Brien et al (1969) found that the extent of bruising in fruit in-transit depended on the frequency, amplitude, and duration of applied vibration as well as the initial condition of the fruit. It was determined that vibration injured the fruit more than impaction (Goff \& Twede 1979). Jarimopas et al (2005) stated that fruit damage can occur on unpaved roads (laterite), while the packages are transported from farms and harvesting areas to regional truck terminals and damage on asphalt road conditions was minimal.

Vibration injury can also cause discoloration of the fruit surface and inflict fresh wounds for pathogen penetration (Crisosto et al 1995). Marcondes \& Sing (1989) found that the most deformation occurred by frequency of 3-7 $\mathrm{Hz}$. Fisher et al (1992) stated that the injury level was affected from acceleration as well. Jarimopas et al (2005) declared that the increase in transportation speed resulted in an increase in vibration levels and damage to packaged fruit. Kasmire \& Kader (1978) stated that injury can be caused by rough handling during loading inadequate packing, and excessive vibration during transport and or load shifts during transport. Çakmak et al (2007) found that the quality losses of fresh fig fruits were decreased upside down position in the boxes during the transportation. Particularly, the exudation was found less at the top position of ostiole-end of fresh fig fruits in the boxes.

In fig varieties, Yediveren, Sarilop and Bursa Black have a great importance for the internal and export markets. Yediveren is an early variety (JuneJuly) for export market. Sarilop is mid season variety (July-August) and known as high standard dried variety. It can be consumed as both fresh and dried. Bursa Black is high quality late season (August-September) fresh variety. These varieties are generally transported in early July, in August and late September in Turkey. Refrigerated trucks are only used for long trips for transportation of fresh figs in Turkey. Commonly used trucks for transportation of agricultural products including fig fruits have double rear axle powered leaf steel spring suspensions.

The objectives of this study were to assess the transportation injury of fresh figs and to compare different packaging materials on fruit quality losses of three fresh fig varieties.

\section{Materials and Methods}

\subsection{Materials}

In this study, the assessment of transportation injury of fresh fig fruits was investigated. Three fig varieties namely Yediveren, Sarilop and Bursa Black were examined. The fresh fig fruits were handpicked from orchard in Erbeyli, Kemalpaşa and Turgutlu located in the Aegean Region then varieties were carefully transported from orchard to packaging laboratory of The Turkish Standardization Institute in Izmir. The main characteristics of fresh fig fruits were determined such as fruit shape index, mass, internal temperature (measured by standard thermometer) and Magness-Taylor flesh firmness (measured by probe with diameter of $8 \mathrm{~mm}$ ) (Table 1).

\subsection{Methods}

In Turkey, the fresh fig fruits are directly transported from orchard to the market or from orchard to packinghouse and then the market. In general, two road types are used for transportation; off-road (rough road) which is farm road and divided and asphalt covered road named as highway in article. Transportation distance ranges 2-60 km for off-road and 15-700 km ranging for smooth divided highway. Main characteristics of the truck and the position of transducer are given in Table 2 and Figure 1, respectively.

Vibration values (frequencies and accelerations) were measured at the vertical direction on floor of fully loaded truck in real transportation conditions. The piezoelectric accelerometer (Type 4396, Brüel \& Kjær) was mounted on the floor of truck (Figure 1). This accelerometer was connected to a portable 
Table 1-Means and standard errors some physical properties of fresh fig fruits Çizelge 1-Taze incir meyvesinin bazı fiziksel özellikleri ve standart hatalart

\begin{tabular}{lrrr}
\hline & \multicolumn{3}{c}{ Fig varieties } \\
\cline { 2 - 4 } Main fruit characteristics & \multicolumn{1}{c}{ Sarilop } & Bursa Black & Yediveren \\
\hline Fruit shape index, h/d & $0.81 \pm 0.02$ & $0.87 \pm 0.01$ & $0.97 \pm 0.02$ \\
Shape & Oblate Spheroid & Spheroid & Spheroid \\
Fruit mass, g & $56.58 \pm 2.30$ & $60.80 \pm 4.20$ & $71.71 \pm 4.10$ \\
Fruit internal temperature, ${ }^{\circ} \mathrm{C}$ & $16.30 \pm 0.20$ & $19.40 \pm 0.40$ & $21.10 \pm 0.30$ \\
Fruit firmness, $\mathrm{N}$ & $6.10 \pm 0.30$ & $7.65 \pm 0.30$ & $7.25 \pm 0.40$ \\
\hline
\end{tabular}

Table 2-Main characteristics of the examined truck

Çizelge 2-Kullanılan kamyonun genel karakteristiği

\begin{tabular}{lc}
\hline Characteristics & \\
\hline Date of manufacturing & 2001 \\
Mass, t & 8.6 \\
Loaded mass during test, $\mathrm{t}$ & 25 \\
Maximum admissible load, $\mathrm{t}$ & 28 \\
Number of axles & 2 \\
Suspension & Leaf spring (front and rear) \\
Tire inflation, bar & 8.6 \\
\hline
\end{tabular}

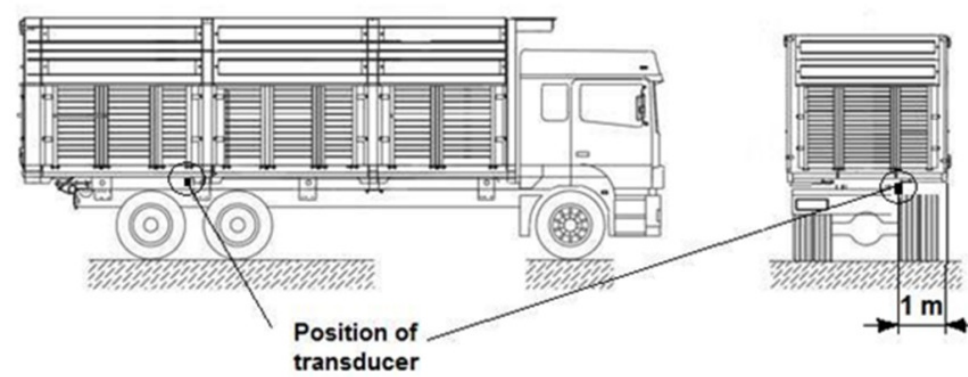

Figure 1-Truck with double rear axle powered leaf steel spring suspensions using for transportation of agricultural products in Turkey

Şekil 1-Türkiye'de tarımsal ürün taşınmasında kullanılan çift arka akslı ve makaslı kamyon

data acquisition system via cable. A portable PULSE system, which was developed by Brüel \& Kjær-Denmark, was used to measure vibration. This system (Type $3650 \mathrm{C}$ ) consists of a PC with LAN interface, PULSE software (Noise and Vibration Analysis Type 7700G), and data acquisition front-end hardware. PULSE 5.1 software provides a graphical user interface for measuring system and serves as a platform for other analyzers and accessories.

The frequency and acceleration of vibration measurements were carried out on different road stretches of entire routes $(\sim 600 \mathrm{~km}, 10 \mathrm{~h})$ in real road conditions. Recordings each lasted 240 seconds were taken randomly during entire routes. Each signal was analyzed with resolution of $1 \mathrm{~Hz}$ by using of Fast Fourier Transformation (FFT) algorithm to determine the power spectral density (PSD). The signals were processed to determine the root mean square value (RMS) by using PULSE system. Then the main PSD peaks were considered to obtain simplified PSD profiles (Barchi et al 2002) and these profiles were used to generate an electrohyraulic-shaker (Shinken Co.Ltd., Japan) (Figure 2). 
Three packaging boxes made from different materials, two types of polystyrene and cardboard, were used to examine the effects of different type of packaging material on the quality losses of three different varieties of fresh fig fruits in the experiment. Polystyrene packaging boxes were manufactured as a prototype by using extruded polystyrene boards (ExtPB $20 \mathrm{~kg} \mathrm{~m}^{-3}$, layer thickness $25 \mathrm{~mm}$, three layers) (Figure 3-A), and expanded polystyrene boards (ExpPB $15 \mathrm{~kg} \mathrm{~m}^{-3}$, thickness of each layer $40 \mathrm{~mm}$, two layers) (Figure $3-\mathrm{B})$. The box made of cardboard materials is widely used for transportation of fresh fig fruits in Turkey (Figure 3-C).

Special sections were made in the polystyrene boards to fit each fig fruit easily. In general, shape index can give an idea to design of the sections in the box. It is possible to calculate the shape index by using of the dimension of fruits. Shape indexes of three varieties of fresh fig fruits were calculated by using the following equation (Çakmak et al 2007);

$$
\text { Shape Index }=\frac{\text { Height }(\mathrm{h})}{\text { Mean Diameter }(\mathrm{d})}
$$

Fresh fig fruits were put tightly inside of boxes and all of them were placed on the table of the shaker and fitted as one layer using special shaker belts. The polystyrene boxes were filled with 12 fruits, and cardboard box was filled 8 fruits for each varieties. The fruits were wrapped with sheets of tissue paper before placing in the polystyrene boxes.

According to road quality, vibration values changes. The PSD values were obtained as $3 \mathrm{~Hz} \sim 0.56 \mathrm{~m} \mathrm{~s}^{-2}$ and $16 \mathrm{~Hz} \sim 2.54 \mathrm{~m} \mathrm{~s}^{-2}$ for off-road and highway, respectively. A PSD peak at $3 \mathrm{~Hz}$ due to rough road was characterized as a first spectrum. Displacement is more on the farm road than highway. The second spectrum was characterized as predominantly by PSD peak at $16 \mathrm{~Hz}$. These PSD peak results were confirmed by Pierce et al (1992). On the other hand, Slaughter et al (1993) and Barchi et al (2002) enunciated the same results for highway transportation using truck with air ride suspension system in their studies. A special electrohydraulic-shaker was used to generate these profiles $\left(16 \mathrm{~Hz} 2.54 \mathrm{~m} \mathrm{~s}^{-2}, 30\right.$ minutes for each shaking test and $3 \mathrm{~Hz} \sim 0.56 \mathrm{~m} \mathrm{~s}^{-2}, 30$ minutes for each shaking test) in the laboratory experiment.

For each variety, 256 samples were used in vibration tests in laboratory and 8 samples as control samples were selected randomly for each variety. In this laboratory experiments, there were four replications for each treatments. Vibration was not applied to control samples. Control and vibrated samples were stored for 48 hours under the controlled atmosphere room $\left(22 \pm 2^{\circ} \mathrm{C}, \mathrm{RH} 60-70 \%\right)$ and after 48 hours analyzed for the following quality attributes by four experts at the same time but separately.

The fresh fig fruits were visually inspected and scored for external damage such as rate of cracking, exudation, mold formation, peeling of fruit skin, rate of shriveling, off-color. Experts used five point scale where $0=$ no damage, $1=$ slight, $2=$ moderate, $3=$ severe, 4=extreme (Eduardo et al 1987; Slaughter et al 1993, 1997). Visually inspected quality attributes of fresh fig fruits and their scores were given in Table 3. Total damage score levels up to 2 were considered as unmarketable fruit.

The interior damage of the fresh fig fruits were evaluated by changes of internal fruit temperature, mass loss, and firmness. Mass loss was calculated as a mass difference of fresh fig fruit between before and after the test. In order to determine fruit mass losses, before and after vibration tests, fruits were weighed. Internal fruit temperature was measured by thermometer inserted in the fruit after tests and then compared with temperature of control samples. Eight fresh fig fruits for each variety were left without vibration treatments as control samples under the same controlled atmosphere conditions in the laboratory. Magness-Taylor flesh firmness was used for measuring firmness of fresh fig fruits in order to compare the firmness of fruit. These measurements were taken from both vibrated fresh fig fruits and controlled samples. Quality losses of the fruits subjected to vibration and controlled samples were compared with each other. All of the results were evaluated by using analysis of variance (ANOVA) method using SPSS V15. 


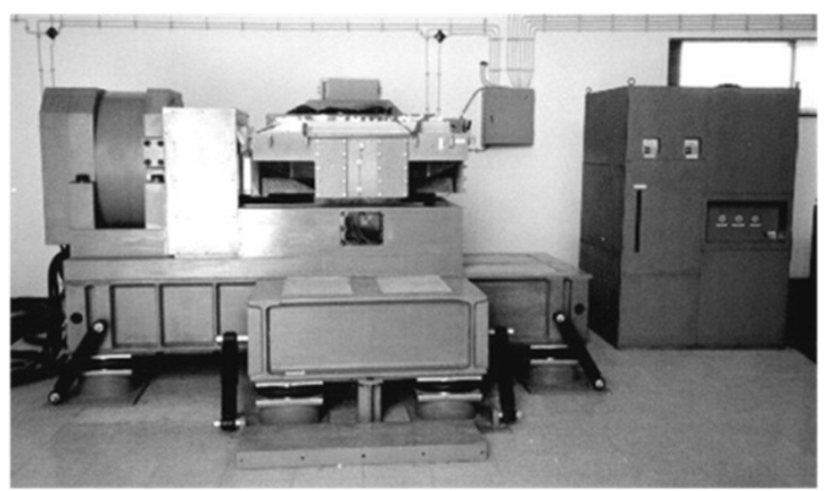

Figure 2-Electro-hydraulic shaker used in experiment Şekil 2-Denemede kullanılan elektrohidrolik sarsıcı
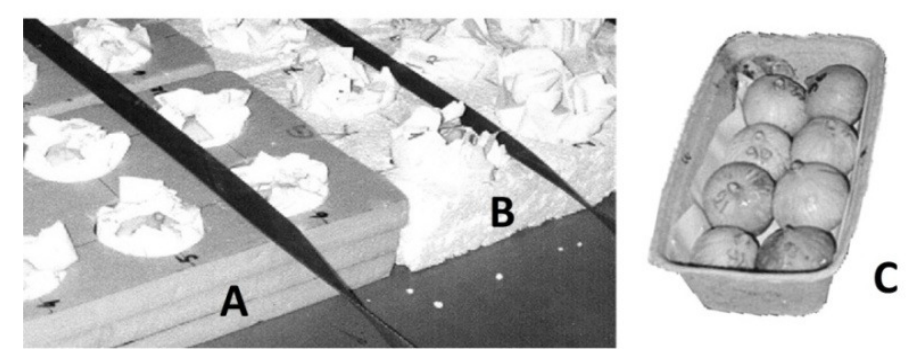

Figure 3-Prototype ExtPB (A), ExpPB (B) packaging boxes and the carboard packaging box $(C)$ which is commonly used in transportation of fresh fig fruits in Turkey

Şekil 3-Prototip $\operatorname{ExtPB}(A), \operatorname{Exp} P B(B)$ taşıma kutularl ve Türkiye'de taze ürünlerin taşınmasında kullanılan karton kutu $(C)$

Table 3-Score tables of visually inspected quality attributes of fresh fig fruits Çizelge 3-Taze incir meyvesinin görsel değerlendirmesinde kullanılan kalite kriterleri puanlaması

\begin{tabular}{|c|c|c|c|}
\hline Visual attributes & 0 & $\begin{array}{c}1 \\
\text { (slight damage) }\end{array}$ & $\begin{array}{c}4 \\
\text { (extreme damage) }\end{array}$ \\
\hline Rate of cracking (0-4 scale) & None & $\begin{array}{l}\text { Total length of crack on flesh of fig fruit } \\
\text { less than } 1 \mathrm{~cm}\end{array}$ & $\begin{array}{l}\text { Total length of crack on flesh } \\
\text { of fig fruit more than } 4 \mathrm{~cm}\end{array}$ \\
\hline $\begin{array}{l}\text { Exudation ( } 0-4 \text { scale), } \\
\text { The liquid from the ostiole of fruit, which is } \\
\text { sweet and intensive form, is called as exudation. } \\
\text { Wetted area was measured on the tissue paper } \\
\text { wrapped. }\end{array}$ & None & Total wetted area less than $1 \mathrm{~cm}^{2}$ & $\begin{array}{l}\text { Total wetted area more than } \\
4 \mathrm{~cm}^{2}\end{array}$ \\
\hline Mold formation ( $0-4$ scale) & None & $\begin{array}{l}\text { Total area of mould formation less than } \\
1 \mathrm{~cm}^{2} \text { on the skin of fresh fig fruit }\end{array}$ & $\begin{array}{l}\text { Total area of mould formation } \\
\text { more than } 4 \mathrm{~cm}^{2} \text { on the skin of } \\
\text { fresh fig fruit }\end{array}$ \\
\hline Peeling of Fruit Skin (0-4 scale) & None & $\begin{array}{l}\text { Total peeled area less than } 1 \mathrm{~cm}^{2} \text { on the } \\
\text { skin of fresh fig fruit }\end{array}$ & $\begin{array}{l}\text { Total peeled area more than } \\
4 \mathrm{~cm}^{2} \text { on the skin of fresh fig } \\
\text { fruit }\end{array}$ \\
\hline Rate of shriveling (0-4 scale) & None & $\begin{array}{l}\text { Total shriveled area less than } 1 \mathrm{~cm}^{2} \text { on the } \\
\text { skin of fresh fig fruit }\end{array}$ & $\begin{array}{l}\text { Total shriveled area more than } \\
4 \mathrm{~cm}^{2} \text { on the skin of fresh fig } \\
\text { fruit }\end{array}$ \\
\hline Off-color (0-4 scale) & None & Total off-coloured area less than $1 \mathrm{~cm}^{2}$ & $\begin{array}{l}\text { Total off-coloured area more } \\
\text { than } 4 \mathrm{~cm}^{2} \text { on the skin of fresh } \\
\text { fig fruit }\end{array}$ \\
\hline
\end{tabular}




\section{Results and Discussion}

\subsection{Road characterization}

The average and maximum speed of truck, the distance travelled, the acceleration rms values and frequency of the PSD peaks for profiles are given in Tables 4 \& 5 for off-road and highway road conditions, respectively. The stretch 1 was selected for characterizing off-road (badly rutted pothole filled old way) because of its high acceleration level. The stretch 11 was selected for characterizing highway (partly new covered with asphalt) because of its high acceleration level.

The calculated PSD values of transportation are illustrated in Figures 4 \& 5 for off-road and highway, respectively. Some rms values are given in Figure 6 (stretch 1 of off-road are given Table 4)

Table 4-Main characteristics of stretches of off-road Çizelge 4-Bozuk yolda gidilen taşıma hatlarının temel karakteristikleri

\begin{tabular}{|c|c|c|c|c|c|c|c|}
\hline Type of off-road & & $\begin{array}{l}\text { Duration, } \\
\text { min }\end{array}$ & $\begin{array}{c}\text { Distance, } \\
\mathrm{km}\end{array}$ & $\begin{array}{l}\text { Max speed, } \\
\mathrm{km} \mathrm{h}^{-1}\end{array}$ & $\begin{array}{c}\text { Average speed, } \\
\mathrm{km} \mathrm{h}^{-1}\end{array}$ & $\begin{array}{l}R M S^{*} \\
m s^{-2}\end{array}$ & $\begin{array}{c}\text { Peak PSD** } \\
\text { Frequency, } \mathrm{Hz}\end{array}$ \\
\hline 1 Farm road & Badly rutted way & 10 & 4 & 25 & 25 & 0.56 & 3 \\
\hline 2 Old way & $\begin{array}{l}\text { Pothole filled two } \\
\text { way road }\end{array}$ & 22 & 11 & 35 & 30 & 0.56 & 3 \\
\hline 3 Old way & $\begin{array}{l}\text { Pothole filled two } \\
\text { way road }\end{array}$ & 30 & 15 & 30 & 30 & 0.43 & 3 \\
\hline 4 Old way & $\begin{array}{l}\text { Connection road to } \\
\text { highway }\end{array}$ & 42 & 21 & 45 & 30 & 0.54 & 3 \\
\hline
\end{tabular}

* Root mean square (rms) acceleration of the simplified profile used to simulate transport vibrations

**PSD, power spectral density

Table 5-Main characteristics of stretches of highway Çizelge 5-Otoyolda gidilen taşıma hatlarının temel karakteristikleri

\begin{tabular}{|c|c|c|c|c|c|c|c|}
\hline Type of road & & $\begin{array}{l}\text { Duration, } \\
\text { min }\end{array}$ & $\begin{array}{l}\text { Distance, } \\
\mathrm{km}\end{array}$ & $\begin{array}{l}\text { Max speed, } \\
\mathrm{km} \mathrm{h}^{-1}\end{array}$ & $\begin{array}{l}\text { Average speed, } \\
\mathrm{km} \mathrm{h}^{-1}\end{array}$ & $\begin{array}{l}R M S^{*} \\
m s^{-2}\end{array}$ & $\begin{array}{c}\text { Peak PSD }{ }^{* *} \\
\text { Frequency, } \mathrm{Hz}\end{array}$ \\
\hline 1 Bypass road & highway & 5 & 5 & 70 & 65 & 2.33 & 16 \\
\hline 2 & highway & 41 & 48 & 85 & 70 & 2.03 & 16 \\
\hline 3 & highway & 39 & 49 & 85 & 75 & 1.81 & 17 \\
\hline $\begin{array}{l}4 \text { Newly coated } \\
\text { with asphalt }\end{array}$ & highway & 64 & 75 & 90 & 70 & 1.73 & 16 \\
\hline 5 & highway & 52 & 61 & 80 & 70 & 2.17 & 16 \\
\hline $\begin{array}{l}6 \text { Newly coated } \\
\text { with asphalt }\end{array}$ & highway & 56 & 70 & 85 & 75 & 1.79 & 16 \\
\hline 7 & highway & 43 & 50 & 85 & 70 & 2.13 & 15 \\
\hline 8 & highway & 15 & 19 & 80 & 75 & 2.29 & 16 \\
\hline $\begin{array}{l}9 \text { Newly coated } \\
\text { with asphalt }\end{array}$ & highway & 64 & 75 & 80 & 70 & 2.12 & 16 \\
\hline 10 & highway & 40 & 47 & 85 & 70 & 2.11 & 16 \\
\hline 11 & highway & 39 & 45 & 75 & 70 & 2.54 & 15 \\
\hline 12 Bypass road & highway & 4 & 4 & 75 & 65 & 2.38 & 16 \\
\hline
\end{tabular}

* Root mean square (r.m.s) acceleration of the simplified profile used to simulate transport vibrations

**PSD, power spectral density 


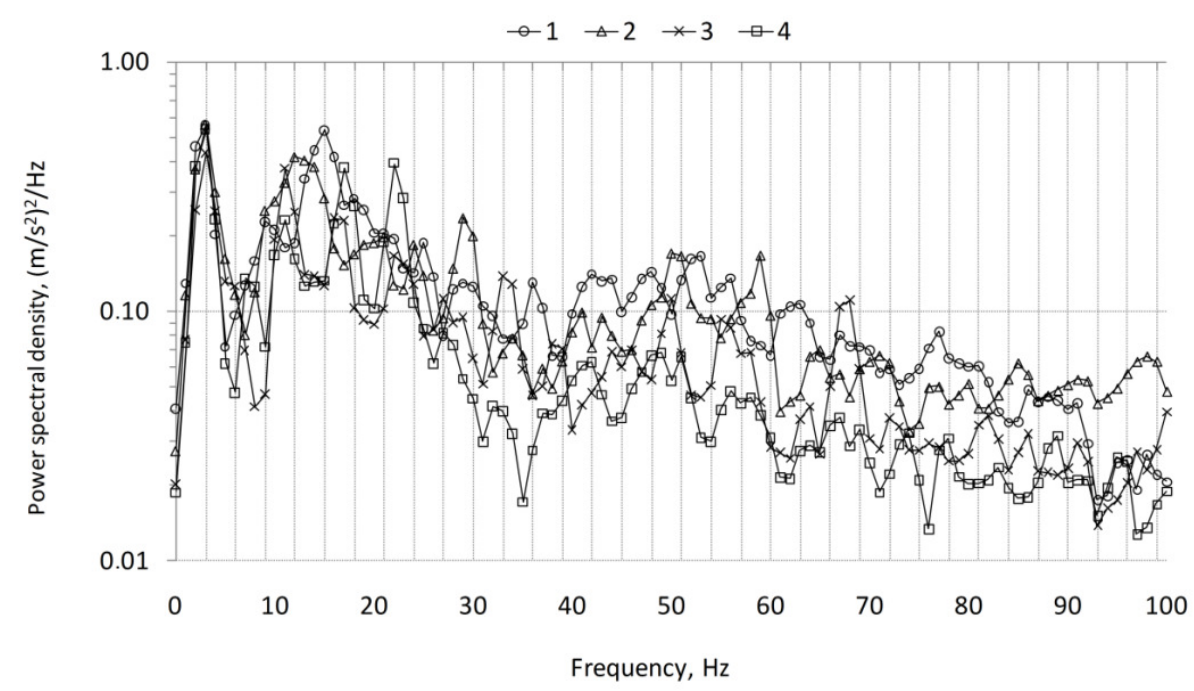

Figure 4-Power density spectra in fully loaded truck for stretches $(1,2,3$ and 4$)$ of off-road (farm and old way)

Şekil 4-Tam yüklü kamyonun PSD spektrumu (çiftlik yolu)

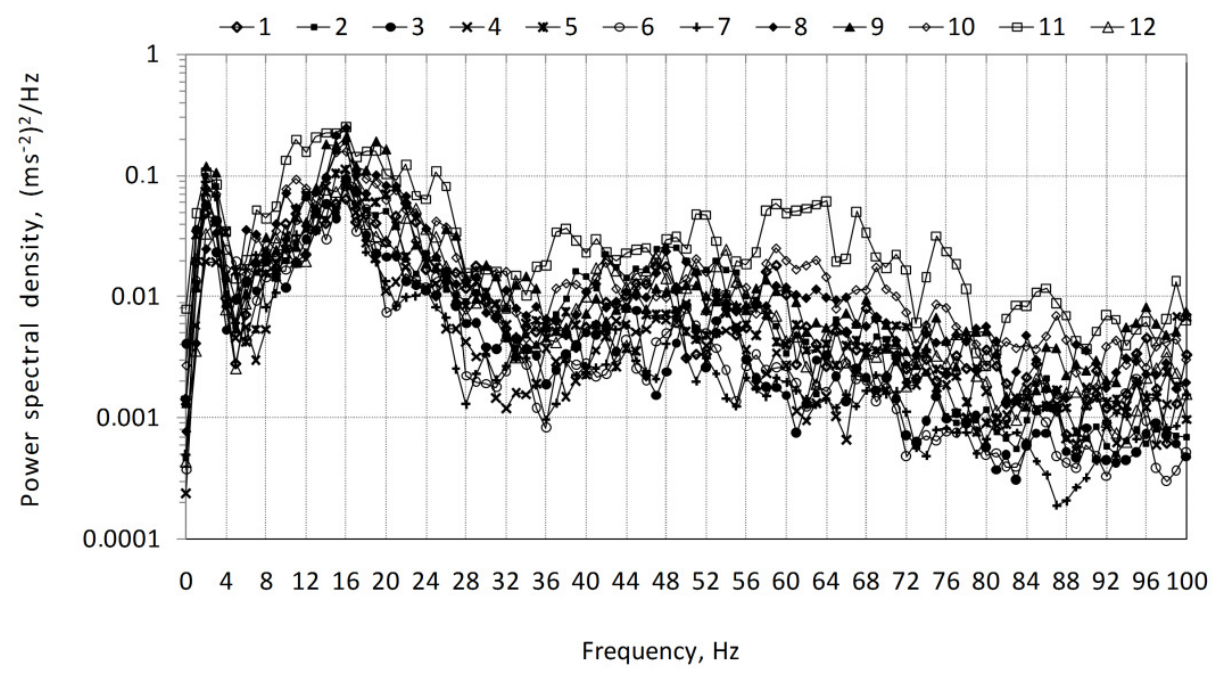

Figure 5-Power density spectra in fully loaded truck for stretches $(1,2,3,4,5,6,7,8$, $9,10,11$ and 12) of highway

Şekil 5-Tam yüklü kamyonun PSD spektrumu (düzgün yüzeyli karayolu-otoyol)

and Figure 7 (stretch 11 of highway in Table 5), depending on the selected stretch profiles for laboratory experiments. In the summer season, asphalt roads are affected by hot climatic condition and softened. After travelling of heavy trucks, badly rutted potholes occur. When only these potholes fill by asphalt, it causes more vibration. This kind of roads should be covered totally by asphalt again. Jarimopas et al (2005) also expressed that fruit damage can occur on off roads. 


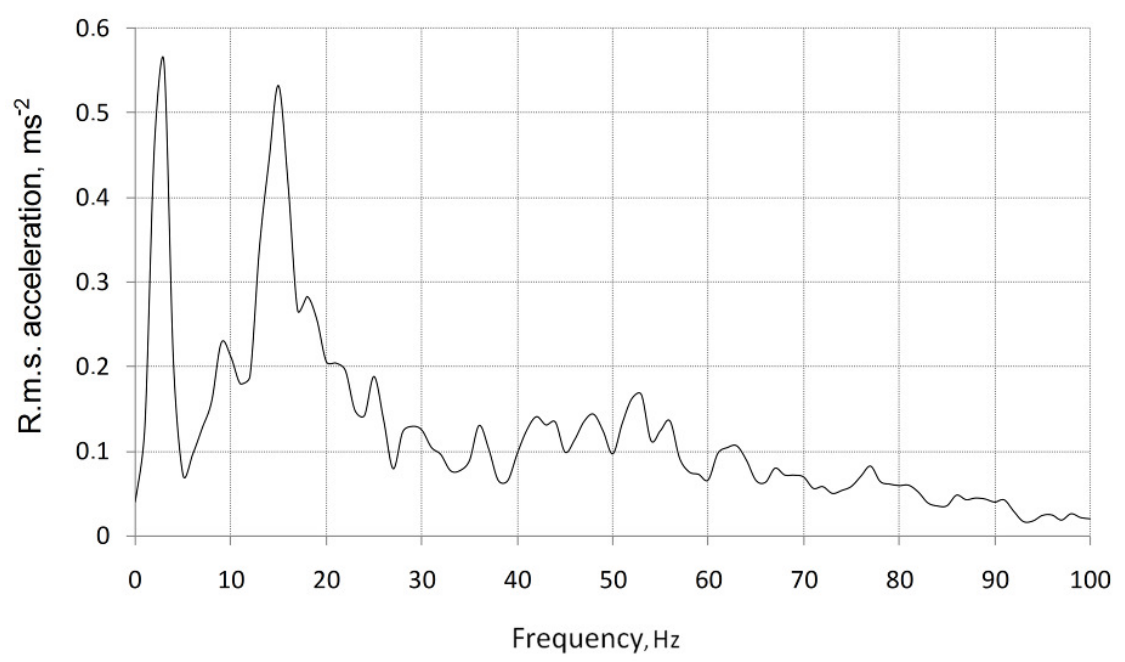

Figure 6-Root mean square acceleration spectra for submitted to PSD profile for entire route (see table 4 stretch 1)

Şekil 6-Belirtilen güzergâh için rms ivme spektrumu (bkz çizelge 4, hat 1)

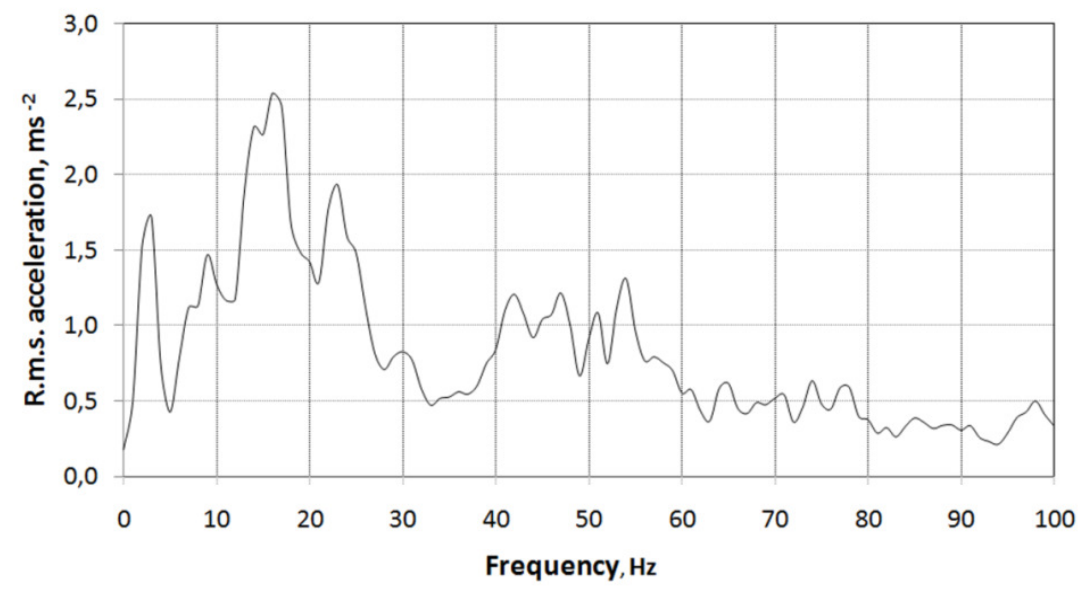

Figure 7-Root mean square acceleration spectra for submitted to PSD profile for entire route (see Table 5 stretch 11)

Şekil 7-Belirtilen güzergâh için rms ivme spektrumu (bkz Çizelge 5, hat 11)

\subsection{Results of visual attributes}

Effects of road conditions and packaging materials on all fig varieties were found statistically significant during transportation. The road effect during transportation on the visual attributes of fresh figs is given in Figures $8 \& 9$. The cumulative effect of highway conditions $\left(16 \mathrm{~Hz} 2.54 \mathrm{~m} \mathrm{~s}^{-2}\right)$ on the all visual attributes of the figs were five times higher than the off-road conditions $\left(3 \mathrm{~Hz} \sim 0.56 \mathrm{~m} \mathrm{~s}^{-}\right.$ ${ }^{2}$ ). Highway road conditions severely affected the figs quality in all six visual attributes because of long transportation time. Although highway conditions have much smoother road conditions than off-road conditions, high acceleration created this visual harmful effect on the fresh fig fruits. 


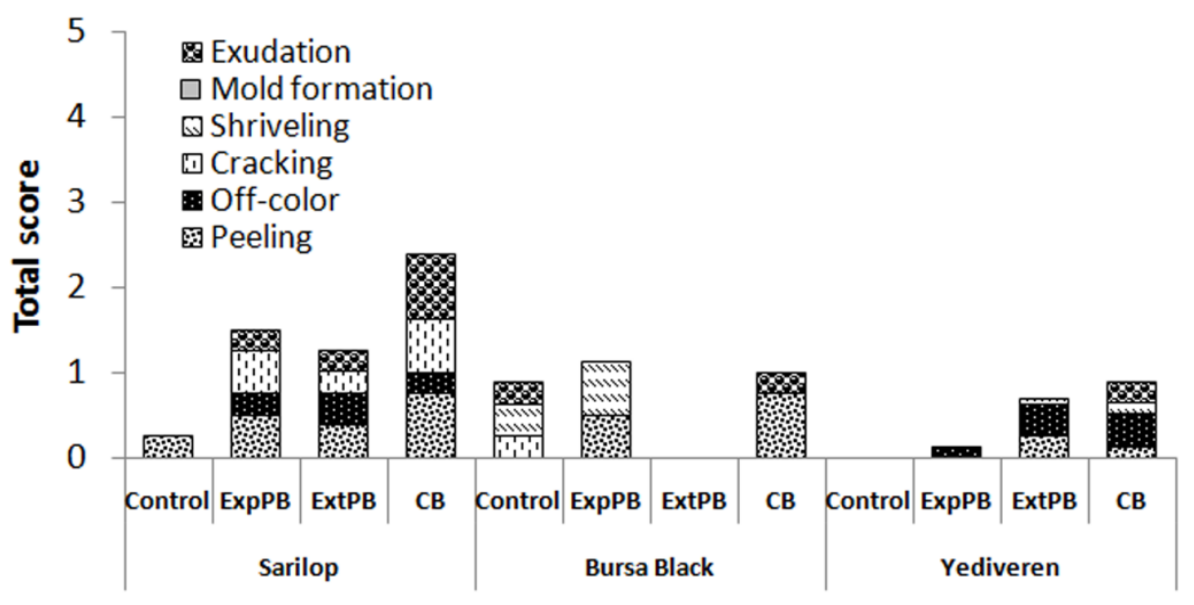

Figure 8-Off-road ( $3 \mathrm{~Hz} \sim 0.56 \mathrm{~m} \mathrm{~s}^{-2}$ ) effect during transportation on the visual attributes of fresh figs in the laboratory experiment (ExpPB: Expanded polystyrene box, ExtPB: Extruded polystyrene box, CB: Cardboard box)

Sekil 8-Laboratuar denemelerinde bozuk yolda $\left(3 \mathrm{~Hz} \sim 0.56 \mathrm{~m} \mathrm{~s}^{-2}\right)$ tașımanın taze incir meyvesinin görsel kalite kriterleri üzerine etkisi (ExpPB: Ekspande polistiren kutu, ExtPB: Ekstrüde polistiren kutu, CB: Karton kutu)

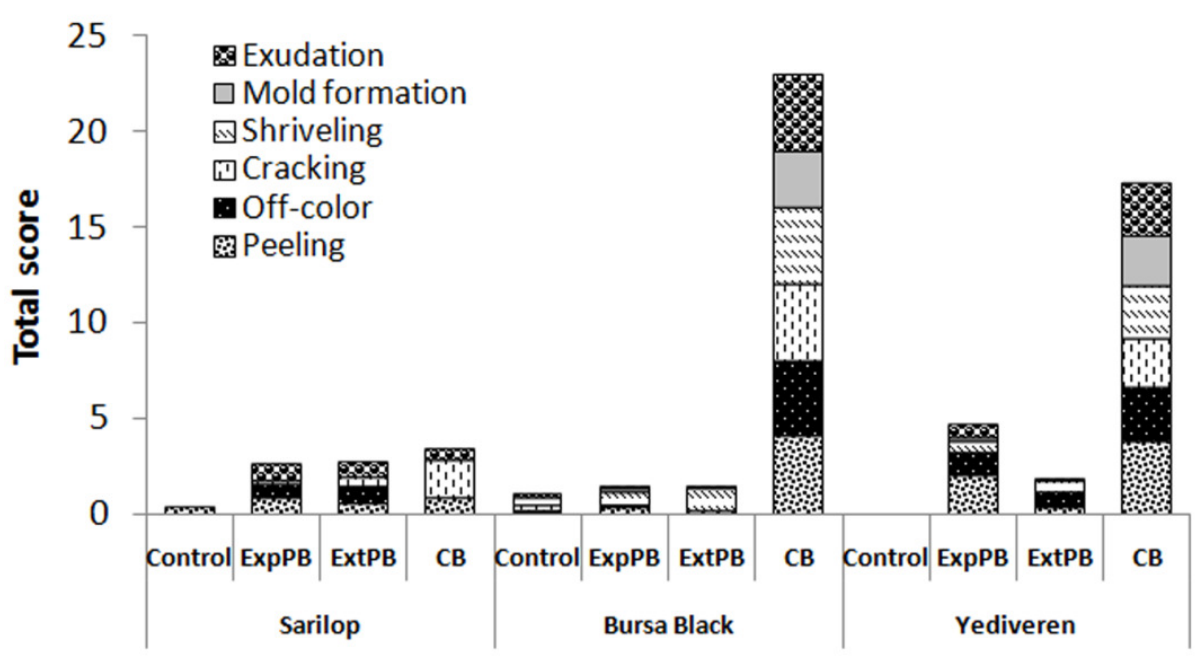

Figure 9-Highway $\left(16 \mathrm{~Hz} 2.54 \mathrm{~m} \mathrm{~s}^{-2}\right)$ effect during transportation on the visual attributes of fresh figs in the laboratory experiment (ExpPB: Expanded polystyrene box, ExtPB: Extruded polystyrene box, CB: Cardboard box)

Sekil 9-Laboratuar denemelerinde otoyolda (16 Hz 2.54 $\mathrm{m} \mathrm{s}^{-2}$ ) taşımanın taze incir meyvesinin görsel kalite kriterleri üzerine etkisi (ExpPB: Ekspande polistiren kutu, ExtPB: Ekstrüde polistiren kutu, CB: Karton kutu) 
Effect of packaging boxes on the visual attributes of fresh figs is depicted in Figures $8 \& 9$. The figs were harmed much more in the cardboard boxes comparing the ExtPB and ExpPB polystyrene boxes during long transport. While cardboard boxes severely affected the figs quality in all six visual attributes, polystyrene boxes provided much safer conditions during transportation in generally. ExtPB boxes had less damage to the visual attributes of the figs than the ExpPB boxes.

Effect of variety including packaging and road conditions on the visual attributes of the figs can also be seen in Figures $8 \& 9$. The effect of transportation on the fig varieties was found to be statistically significant. Sarilop variety was found to be much sensitive to the transportation as compared to Bursa Black and Yediveren varieties in off-road conditions. Sarilop variety has more damage than two other varieties in highway conditions except packaging with CB box. Generally, Bursa Black and Yediveren were more suitable for long transportation packaged with polystyrene boxes in all six visual attributes.

Cumulative effect of transportation on the visual attributes of the figs for off-road and highway conditions are shown in Tables $6 \& 7$, respectively. It is clear from Table 7 that transportation with cardboard boxes in the highway conditions had the most damage on the visual attributes of the figs. Transportation with cardboard boxes quite damaged to Bursa Black in highway conditions. Comparing other two varieties, Sarilop had less damage during transportation with cardboard boxes. On the other hand, Bursa Black and Yediveren varieties had less damage when polystyrene boxes were used for transportation in general.

\subsection{Results of measured attributes}

Effects of road during transportation on the measured attributes of mass loss, firmness, and internal temperature of fresh figs are given in Tables $6 \& 7$. The cumulative effect of highway conditions $\left(16 \mathrm{~Hz} 2.54 \mathrm{~m} \mathrm{~s}^{-2}\right)$ increased the mass loss of the figs during transportation comparing the off-road conditions $\left(3 \mathrm{~Hz} \sim 0.56 \mathrm{~m} \mathrm{~s}^{-2}\right)$. Although highway road conditions increased the mass loss, firmness of the figs was not affected from the road conditions statistically.
Effect of packing box materials on the measured attributes of fresh figs is also shown in Tables $6 \&$ 7. The mass losses of the figs were about four times in the cardboard boxes comparing the ExtPB and ExpPB polystyrene boxes in highway conditions. The transportation effect of polystyrene boxes on the mass loss of the figs was found to be non significant but firmness and internal temperature found significant statistically in off-road conditions. ExtPB boxes provided better transportation for mass loss and firmness of the figs comparing ExpPB polystyrene boxes.

Effect of variety including packaging box in both road conditions on the measured attributes of fresh figs is given in Tables $6 \& 7$. While Bursa Black variety had the least mass loss and good firmness, Yediveren variety was found to be very sensitive to the transportation for mass loss and firmness of the Sarilop variety had the worst effect from transportation in off-road conditions. Transportation effect for all measured attributes of the varieties was found to be statistically significant in highway conditions.

\section{Conclusion}

According to the results of the experiment, transportation generally affected the quality of the figs in terms of visual and measured attributes. Highway conditions had more negative effects on the quality of the figs comparing to off-road conditions. This effect was accelerated because of the long transportation time of fruits. It was found that cardboard packaging materials are not convenient for transportation in any road conditions. Polystyrene boxes decreased the negative effect of transportation comparing with the cardboard boxes.

All fig varieties, Bursa Black, Yediveren and Sarilop were affected from the road conditions and packaging boxes. Cardboard boxes are not convenient for transportation of the figs. ExtPB boxes were found to be the best packaging material for transportation in all conditions.

Generally, transportation caused mass losses in the figs and somehow changed the firmness of the figs. Transportation with cardboard boxes increased the internal temperatures of the figs which finally 
Table 6-Cumulative effect of off- $\operatorname{road}\left(3 \mathrm{~Hz} \sim 0.56 \mathrm{~m} \mathrm{~s}^{-2}\right)$ on visual attributes and measured attributes of fresh fig fruits in the laboratory experiment

Çizelge 6- Laboratuar denemelerinde bozuk yolda $\left(3 \mathrm{~Hz} \sim 0.56 \mathrm{~m} \mathrm{~s}^{-2}\right)$ taşımanın görsel ve ölçümsel kalite kriterleri üzerine toplu etkisi

\begin{tabular}{|c|c|c|c|c|c|c|c|c|c|c|c|}
\hline Box type & : & 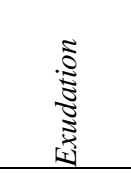 & 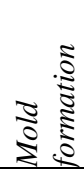 & 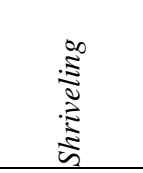 & 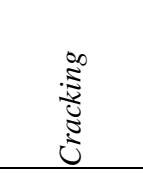 & $\begin{array}{l}0 \\
\vdots \\
0 \\
0 \\
0 \\
0\end{array}$ & $\begin{array}{l}\stackrel{\infty}{\Xi} \\
\stackrel{\Xi}{\Xi} \\
2\end{array}$ & 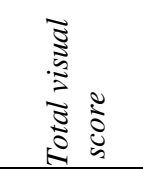 & 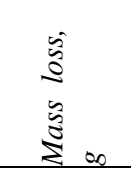 & 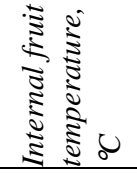 & 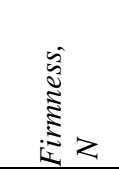 \\
\hline & $\mathrm{Y}$ & 0.00 & 0.00 & 0.00 & 0.00 & 0.13 & 0.00 & 0.13 & 4.16 & 22.8 & 7.07 \\
\hline \multirow[t]{3}{*}{ ExpPB } & $\mathrm{BB}$ & 0.00 & 0.00 & 0.63 & 0.00 & 0.00 & 0.50 & 1.13 & 1.62 & 21.3 & 6.72 \\
\hline & $\mathrm{S}$ & 0.25 & 0.00 & 0.00 & 0.50 & 0.38 & 0.50 & 1.63 & 3.02 & 22.4 & 5.72 \\
\hline & Y & 0.00 & 0.00 & 0.00 & 0.00 & 0.38 & 0.25 & 0.63 & 4.03 & 23.6 & 6.69 \\
\hline \multirow[t]{3}{*}{ ExtPB } & $\mathrm{BB}$ & 0.00 & 0.00 & 0.00 & 0.00 & 0.00 & 0.00 & 0.00 & 1.08 & 21.8 & 7.31 \\
\hline & S & 0.25 & 0.00 & 0.00 & 0.25 & 0.25 & 0.38 & 1.13 & 2.94 & 22.8 & 5.19 \\
\hline & $\mathrm{Y}$ & 0.00 & 0.00 & 0.25 & 0.00 & 0.38 & 0.13 & 0.76 & 3.04 & 21.1 & 6.44 \\
\hline \multirow[t]{3}{*}{$\mathrm{CB}$} & BB & 0.25 & 0.00 & 0.00 & 0.00 & 0.00 & 0.75 & 1.00 & 1.67 & 21.1 & 6.39 \\
\hline & $\mathrm{S}$ & 0.75 & 0.00 & 0.00 & 0.63 & 0.25 & 0.75 & 2.38 & 3.33 & 23.5 & 5.54 \\
\hline & $\mathrm{Y}$ & 0.00 & 0.00 & 0.00 & 0.00 & 0.00 & 0.00 & 0.00 & 0.00 & 25.0 & 7.25 \\
\hline \multirow[t]{2}{*}{ Control } & $\mathrm{BB}$ & 0.25 & 0.00 & 0.38 & 0.25 & 0.13 & 0.00 & 1.01 & 0.00 & 19.5 & 7.65 \\
\hline & $S$ & 0.00 & 0.00 & 0.00 & 0.00 & 0.00 & 0.25 & 0.25 & 0.00 & 16.5 & 6.11 \\
\hline \multicolumn{12}{|c|}{ Main Effects } \\
\hline \multicolumn{2}{|l|}{ ExpPB } & $0.08 \pm 0.06^{\mathrm{b}}$ & 0.00 & $0.21 \pm 0.09^{\mathrm{a}}$ & $0.17 \pm 0.08$ & $0.17 \pm 0.10$ & $0.33 \pm 0.10^{\mathrm{ab}}$ & $0.96 \pm 0.20^{\mathrm{ab}}$ & $2.93 \pm 0.36^{\mathrm{a}}$ & $22.1 \pm 0.21^{b}$ & $6.5 \pm 0.19^{\mathrm{ab}}$ \\
\hline \multicolumn{2}{|l|}{ ExtPB } & $0.08 \pm 0.06^{\mathrm{b}}$ & 0.00 & $0.00^{\mathrm{b}}$ & $0.08 \pm 0.06$ & $0.21 \pm 0.10$ & $0.21 \pm 0.09^{\mathrm{bc}}$ & $0.58 \pm 0.15^{\mathrm{bc}}$ & $2.68 \pm 0.27^{\mathrm{a}}$ & $22.7 \pm 0.20^{\mathrm{a}}$ & $6.6 \pm 0.22^{\mathrm{ab}}$ \\
\hline \multicolumn{2}{|l|}{$\mathrm{CB}$} & $0.33 \pm 0.10^{\mathrm{a}}$ & 0.00 & $0.08 \pm 0.06^{\mathrm{ab}}$ & $0.21 \pm 0.09$ & $0.21 \pm 0.10$ & $0.54 \pm 0.10^{\mathrm{a}}$ & $1.37 \pm 0.25^{\mathrm{a}}$ & $2.68 \pm 0.20^{\mathrm{a}}$ & $21.9 \pm 0.26^{\mathrm{b}}$ & $6.1 \pm 0.20^{\mathrm{b}}$ \\
\hline \multicolumn{2}{|l|}{ Control } & $0.08 \pm 0.06^{b}$ & 0.00 & $0.13 \pm 0.07^{\mathrm{ab}}$ & $0.08 \pm 0.06$ & $0.04 \pm 0.04$ & $0.08 \pm 0.06^{\mathrm{c}}$ & $0.41 \pm 0.16^{\mathrm{c}}$ & $0.00^{\mathrm{b}}$ & $20.3 \pm 0.75^{\mathrm{c}}$ & $7.0 \pm 0.23^{\mathrm{a}}$ \\
\hline \multicolumn{2}{|l|}{$\bar{Y}$} & $0.00^{\mathrm{b}}$ & 0.00 & $0.06 \pm 0.04^{\mathrm{b}}$ & $0.00^{\mathrm{b}}$ & $0.22 \pm 0.07$ & $0.09 \pm 0.05^{\mathrm{b}}$ & $0.37 \pm 0.11^{\mathrm{c}}$ & $2.81 \pm 0.37^{\mathrm{a}}$ & $23.1 \pm 0.29^{\mathrm{a}}$ & $6.9 \pm 0.15^{\mathrm{a}}$ \\
\hline \multicolumn{2}{|l|}{$\mathrm{BB}$} & $0.13 \pm 0.06^{b}$ & 0.00 & $0.25 \pm 0.08^{\mathrm{a}}$ & $0.06 \pm 0.04^{b}$ & $0.03 \pm 0.03$ & $0.31 \pm 0.08^{\mathrm{a}}$ & $0.78 \pm 0.15^{\mathrm{b}}$ & $1.09 \pm 0.14^{\mathrm{c}}$ & $20.9 \pm 0.19^{c}$ & $7.0 \pm 0.20^{\mathrm{a}}$ \\
\hline \multicolumn{2}{|l|}{$\mathrm{S}$} & $0.31 \pm 0.08^{\mathrm{a}}$ & 0.00 & $0.00^{\mathrm{b}}$ & $0.34 \pm 0.09^{\mathrm{a}}$ & $0.22 \pm 0.11$ & $0.47 \pm 0.09^{\mathrm{a}}$ & $1.34 \pm 0.21^{\mathrm{a}}$ & $2.32 \pm 0.26^{\mathrm{b}}$ & $21.3 \pm 0.51^{\mathrm{b}}$ & $5.8 \pm 0.12^{\mathrm{b}}$ \\
\hline \multicolumn{12}{|l|}{$P$ values } \\
\hline \multicolumn{2}{|l|}{ Box } & 0.008 & & 0.004 & 0.336 & 0.516 & 0.001 & 0.005 & 0.000 & 0.000 & 0.000 \\
\hline \multicolumn{2}{|l|}{ Variety } & 0.000 & & 0.000 & 0.000 & 0.152 & 0.001 & 0.000 & 0.000 & 0.000 & 0.010 \\
\hline \multicolumn{2}{|c|}{ Box $\times$ Variety } & 0.006 & - & 0.000 & 0.002 & 0.481 & 0.045 & 0.051 & 0.000 & 0.000 & 0.711 \\
\hline
\end{tabular}

ExpPB: Expanded polystyrene box, ExtPB: Extruded polystyrene box, CB: Cardboard box

Y: Yediveren variety, BB: Bursa Black variety, S:Sarilop variety

decreased the quality of them. The cardboard box which is generally used for packaging fresh fruits is not convenient for transportation of fresh fig fruits. Instead of cardboard box type, polystyrene boxes should be used.

\section{Acknowledgements}

The Scientific \& Technological Research Council of Turkey (TUBITAK) and Science and Technology Research Center of Ege University (EBILTEM) financed this study. 
Table 7-Cumulative effect of highway $\left(16 \mathrm{~Hz} 2.54 \mathrm{~m} \mathrm{~s}^{-2}\right)$ on visual attributes and measured attributes of fresh fig fruits in the laboratory experiment

Çizelge 7- Laboratuar denemelerinde otoyolda $\left(16 \mathrm{~Hz} \sim 2.54 \mathrm{~m} \mathrm{~s}^{-2}\right)$ taşımanın görsel ve ölçümsel kalite kriterleri üzerine toplu etkisi

\begin{tabular}{|c|c|c|c|c|c|c|c|c|c|c|c|}
\hline Box type & 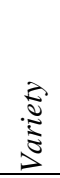 & 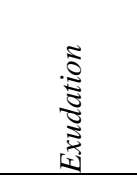 & 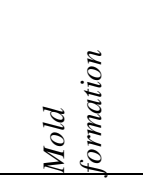 & 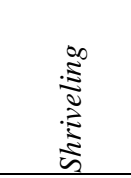 & 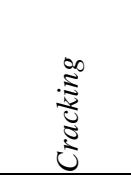 & $\begin{array}{l}\frac{1}{0} \\
0 \\
0 \\
0 \\
0\end{array}$ & $\begin{array}{l}\stackrel{\infty}{\Xi} \\
\stackrel{\Xi}{\Xi} \\
2\end{array}$ & 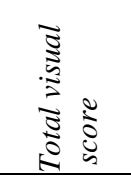 & $\begin{array}{l}\hat{s} \\
\hat{0} \\
\tilde{y} \\
\tilde{s}\end{array}$ & 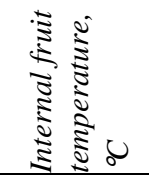 & 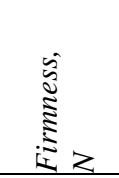 \\
\hline & $\mathrm{Y}$ & 0.75 & 0.13 & 0.63 & 0.00 & 1.13 & 2.00 & 4.64 & 3.60 & 21.9 & 7.00 \\
\hline \multirow[t]{3}{*}{ ExpPB } & $\mathrm{BB}$ & 0.13 & 0.13 & 0.75 & 0.13 & 0.00 & 0.25 & 1.39 & 1.42 & 22.5 & 7.07 \\
\hline & $\mathrm{S}$ & 0.88 & 0.00 & 0.00 & 0.13 & 0.75 & 0.75 & 2.51 & 2.22 & 20.3 & 5.87 \\
\hline & $\mathrm{Y}$ & 0.13 & 0.00 & 0.50 & 0.00 & 0.88 & 0.25 & 1.76 & 2.00 & 22.1 & 6,61 \\
\hline \multirow[t]{3}{*}{ ExtPB } & BB & 0.13 & 0.00 & 1.13 & 0.00 & 0.00 & 0.13 & 1.39 & 1.33 & 20.5 & 7.42 \\
\hline & $\mathrm{S}$ & 0.75 & 0.00 & 0.00 & 0.50 & 0.88 & 0.50 & 2.63 & 2.04 & 21.1 & 5.40 \\
\hline & $\mathrm{Y}$ & 2.75 & 2.63 & 2.75 & 2.50 & 2.88 & 3.75 & 17.26 & 9.34 & 23.9 & 4.81 \\
\hline \multirow[t]{3}{*}{$\mathrm{CB}$} & BB & 4.00 & 4.00 & 4.00 & 4.00 & 4.00 & 4.00 & 24.00 & 10.00 & 27.0 & - \\
\hline & $\mathrm{S}$ & 0.63 & 0.00 & 0.00 & 2.00 & 0.00 & 0.75 & 3.38 & 5.88 & 24.1 & 5.85 \\
\hline & $\mathrm{Y}$ & 0.00 & 0.00 & 0.00 & 0.00 & 0.00 & 0.00 & 0.00 & 0.00 & 25.0 & 7.25 \\
\hline \multirow[t]{2}{*}{ Control } & $\mathrm{BB}$ & 0.25 & 0.00 & 0.38 & 0.25 & 0.13 & 0.00 & 1.01 & 0.00 & 19.5 & 7.65 \\
\hline & $\mathrm{S}$ & 0.00 & 0.00 & 0.00 & 0.00 & 0.00 & 0.25 & 0.25 & 0.00 & 16.5 & 6.11 \\
\hline \multicolumn{12}{|c|}{ Main Effects } \\
\hline \multicolumn{2}{|l|}{ ExpPB } & $0.58 \pm 0.10^{b}$ & $0.08 \pm 0.06^{b}$ & $0.46 \pm 0.13^{b}$ & $0.08 \pm 0.06^{b}$ & $0.63 \pm 0.18^{b}$ & $1.00 \pm 0.24^{b}$ & $2.83 \pm 0.43^{b}$ & $2.42 \pm 0.23^{b}$ & $21.5 \pm 0.28^{b}$ & $6.7 \pm 0.23$ \\
\hline \multicolumn{2}{|l|}{ ExtPB } & $0.33 \pm 0.10^{b c}$ & $0.00^{\mathrm{b}}$ & $0.54 \pm 0.17^{b}$ & $0.17 \pm 0.08^{b}$ & $0.58 \pm 0.20^{b}$ & $0.29 \pm 0.11^{\mathrm{b}}$ & $1.91 \pm 0.33^{\mathrm{bc}}$ & $1.79 \pm 0.08^{\mathrm{c}}$ & $21.3 \pm 0.31^{\mathrm{b}}$ & $6.5 \pm 0.26$ \\
\hline \multicolumn{2}{|l|}{$\mathrm{CB}$} & $2.46 \pm 0.36^{\mathrm{a}}$ & $2.21 \pm 0.41^{\mathrm{a}}$ & $2.25 \pm 0.40^{\mathrm{a}}$ & $2.50 \pm 0.36^{\mathrm{a}}$ & $2.29 \pm 0.39^{\mathrm{a}}$ & $2.83 \pm 0.34^{\mathrm{a}}$ & $14.54 \pm 2.18^{\mathrm{a}}$ & $8.40 \pm 0.52^{\mathrm{a}}$ & $25.0 \pm 0.40^{\mathrm{a}}$ & $6.7 \pm 0.53$ \\
\hline \multicolumn{2}{|l|}{ Control } & $0.08 \pm 0.06^{\mathrm{c}}$ & $0.00^{\mathrm{b}}$ & $0.13 \pm 0.07^{b}$ & $0.08 \pm 0.06^{\mathrm{b}}$ & $0.04 \pm 0.04^{c}$ & $0.08 \pm 0.06^{\mathrm{c}}$ & $0.42 \pm 0.16^{\mathrm{c}}$ & $0.00^{\mathrm{d}}$ & $20.3 \pm 0.75^{\mathrm{c}}$ & $7.0 \pm 0.23$ \\
\hline \multicolumn{2}{|l|}{$\bar{Y}$} & $0.91 \pm 0.25^{\mathrm{a}}$ & $0.69 \pm 0.26^{b}$ & $0.97 \pm 0.25^{b}$ & $0.63 \pm 0.26^{b}$ & $1.22 \pm 0.24^{\mathrm{a}}$ & $1.50 \pm 0.30^{\mathrm{a}}$ & $5.91 \pm 1.46^{\mathrm{a}}$ & $3.73 \pm 0.65^{\mathrm{a}}$ & $23.2 \pm 0.28^{\mathrm{a}}$ & $6.4 \pm 0.28^{b}$ \\
\hline \multicolumn{2}{|l|}{$\mathrm{BB}$} & $1.13 \pm 0.30^{\mathrm{a}}$ & $1.03 \pm 0.31^{\mathrm{a}}$ & $1.56 \pm 0.29^{\mathrm{a}}$ & $1.09 \pm 0.31^{\mathrm{a}}$ & $1.03 \pm 0.31^{\mathrm{a}}$ & $1.09 \pm 0.31^{\mathrm{b}}$ & $6.93 \pm 1.78^{\mathrm{a}}$ & $3.19 \pm 0.71^{b}$ & $22.4 \pm 0.55^{\mathrm{b}}$ & $7.9 \pm 0.23^{\mathrm{a}}$ \\
\hline \multicolumn{2}{|l|}{ S } & $0.56 \pm 0.09^{\mathrm{b}}$ & $0.00^{\mathrm{c}}$ & $0.00^{\mathrm{c}}$ & $0.41 \pm 0.12^{b}$ & $0.41 \pm 0.17^{\mathrm{b}}$ & $0.56 \pm 0.15^{\mathrm{c}}$ & $1.94 \pm 0.35^{\mathrm{b}}$ & $2.54 \pm 0.44^{\mathrm{c}}$ & $20.5 \pm 0.55^{\mathrm{c}}$ & $5.8 \pm 0.22^{\mathrm{c}}$ \\
\hline \multicolumn{12}{|l|}{$P$ values } \\
\hline \multicolumn{2}{|l|}{ Box } & 0.000 & 0.000 & 0.000 & 0.001 & 0.000 & 0.000 & 0.000 & 0.000 & 0.000 & 0.489 \\
\hline \multicolumn{2}{|l|}{ Variety } & 0.002 & 0.000 & 0.000 & 0.000 & 0.000 & 0.000 & 0.000 & 0.000 & 0.000 & 0.000 \\
\hline \multicolumn{2}{|c|}{ Box $\times$ Variety } & 0.000 & 0.000 & 0.000 & 0.000 & 0.000 & 0.000 & 0.000 & 0.000 & 0.000 & 0.000 \\
\hline
\end{tabular}

ExpPB: Expanded polystyrene box, ExtPB: Extruded polystyrene box, CB: Cardboard box

Y: Yediveren variety, BB: Bursa Black variety, S:Sarilop variety

\section{References}

Acıcan T, Alibas K \& Özelkök I S (2007). Mechanical damage to apples during transport in wooden crates. Biosystems Engineering 96(2): 239-248

Aksoy U (1997). Why fig? An old taste and a new perspective. Proceedings of the First International Symposium on Fig. Acta Horticulture 489: 25-26

Alayunt F N, Çakmak B, Can Z \& Aksoy U (2000). A study on vibrational damage to some fig cultivars using a simulator. XXIV. HAS-ATC Research and Development Conference Proceedings. Kutatasi Es Fejlesztesi Tanacskozas. Gödöllö- Hungary No 24

Barchi G L, Berardinelli A, Guarnieri A, Ragni L \& Totaro F C (2002). Damage to loquats by vibrationsimulating intra-state transport. Biosystems Engineering 82(3): 305-312

Bollen, A F. \& De La Rue, B T (1990). Handling impacts for kiwifruit, Asian pears and apples. ASAE Paper No 90-6005 
Burton C L, Brown G K, Shulte P N L \& Timm E J (1989). Apple bruising related to picking and hauling impacts. ASAE Paper No 89-6049

Crisosto C H, Mitchell F G \& Johnson S (1995). Factors in fresh market stone fruit quality. Postharvest News and Information 6(2): 17-21

Çakmak B, Can H Z, Akdeniz R C, Alayunt F N \& Aksoy U (2007). Taze incirin taşınması sırasında paketleme özelliklerinin kalite kayıları üzerine etkisi. Ege Üniversitesi Ziraat Fakültesi Dergisi 44(1): 123-135

Fischer D, Craig W L, Watada A E, Douglas W \& Ashby B H (1992). Simulated intransit vibration damage to packaged fresh market grapes and strawberries. Applied Engineering in Agriculture 8(3): 363-366

Goff J W \& Twede D (1979). Boxes Bags and Cans: Performance of Packages for the Transportation of Agricultural Products. Michigan State University Special Report 14

Jarimopas B, Singh S P \& Saengnil W (2005). Measurement and analysis of truck transport vibration levels and damage to packaged tangerines during transit. Packaging Technology and Science 18: $179-188$

Kasmire R F \& Kader A A (1978). Handling tomatoes at wholesale and retail: A guide for better quality and greater profits. Outlook 5(3): 5-12

Marcondes J \& Sing S B (1989). Dynamic analysis of less than truck load shipment. Paper 88-WA/EEP-17 ASME New York

O'Brien M \& Guillou R (1969). An in-transit vibration Simulator for fruit-handling studies. Transactions of the ASAE 12(1): 94-97

O'Brien M, Gentry J P \& Gibson R C (1965). Vibrating characteristics of fruit as related to in-transit injury. Transactions of the ASAE 8(2): 241-243

Öğüt H, Peker A \& Aydin C (1999). Simulated transit studies on peaches: effect of container, cushion materials and vibrations on elasticity modulus. Agricultural Mechanization in Asia, Africa and Latin America 30(3): 59-62
Özgüven F \& Vursavus K (2002). Domateste oluşan mekanik zedelenme üzerine taşıma sırasındaki titreşim etkilerinin araştırılması. Çukurova Üniversitesi Ziraat Fakültesi Dergisi 17(2): 33-40

Peleg K \& Hinga S (1986). Simulation of vibration damage in produce transportation. Transactions of the ASAE 29(2): 633-641

Pierce C D, Singh S P \& Burgess G (1992). A comparison of leaf spring with air-cushion trailer suspension in the transport environment. Packaging Technology and Science 5: 11-15

Singh A \& Singh Y (1992). Effects of vibration during transportation on the quality of tomatoes. Agricultural Mechanization in Asia, Africa and Latin America 23(2): 70-72

Singh S P \& Xu M (1993). Bruising in apples as a function of truck vibration and packaging. Applied Engineering in Agriculture 9(5): 455-460

Slaughter D C, Hinsch R T \& Thompson J F (1993). Assessment of vibration injury to Bartlett pears. Transactions of the ASAE 36(4):1043-1047

Slaughter D C, Thompson J F \& Hinsch R T (1998). Packaging barlett pears in polyethylene film bags to reduce vibration injury in transit. Transaction of the ASAE 41:107-114

Sommer N F (1957). Surface discoloration of pears. California Agriculture 11(1):3-4

Turczyn M T, Grant S W, Ashby B H \& Wheaton F W (1986). Potato shatter bruising during laboratory handling and transport simulation. Transactions of the ASAE 29(4): 1171-1175

Vergano P J, Testin R F \& Newall Jr W C (1991). Peach bruising: susceptibility to impact, vibration, and compression abuse. Transactions of the ASAE 34(5): 2110-2116

Vursavus K \& Özgüven F (2004). Determining the effects of vibration parameters and packaging method on mechanical damage in golden delicious apple variety. Turkish Journal of Agriculture and Forestry 28: $311-320$ 